Władysław WELFE*

Waldemar FLORCZAK*

\title{
Slowdown of the Polish Economy: Model-Based Simulations
}

\section{Introduction}

The global economic crisis that was triggered by the financial meltdown in the United States in 2008 gave rise to a worldwide recession in 2009. The recession had a deep impact on all industrial countries, especially those in the European Union. Nearly all European countries experienced a recession in 2009. Poland was the only country that escaped it; however, Poland suffered a deep decline in the rates of growth, especially in foreign trade.

Our aim is to explain why the Polish economy did not run into recession in 2009. The shocks that came from the world's financial markets were absorbed by the Polish economy without deep losses. The value of shares declined, but the financial position of banks and firms did not deteriorate seriously.

The transmission of the world recession came mainly through a deep decline of exports. It was to an extent moderated by an unexpected increase in the exchange rates of the zloty against the dollar and euro. Slower business in export-oriented industries following a depreciation of the zloty had an adverse effect on imports. As a result net exports increased.

Domestic final demand did not change much. Consumption declined slowly, mainly due to a decrease in employment. Real disposable income rates remained positive as a result of a combination of fiscal policy (reduced personal taxes) and monetary policy (decreased interest rates). Due to habit persistence, private consumption continued to grow at a rate of more than $2 \%$ in 2009.

Investment declined seriously because of growing investment risks and pessimistic expectations associated with a decline in foreign direct investment (FDI). An inflow of EU investment funds and the decrease in interest rates helped constrain this decline. Despite pessimistic forecasts, the volume of investment outlays declined by only $0.3 \%$ in 2009 .

The initial budget deficit target was raised in mid-2009, preventing a decline in government consumption.

The total impact of changes in net exports and domestic final demand resulted in a $1.7 \%$ increase in GDP.

The authors work at the Faculty of Econometric Models and Forecasts of the University of Łódź, Poland (W. Welfe e-mail: emfiws@uni.lodz.pl, W. Florczak e-mail: emfwaf@uni.lodz.pl). The article was submitted in July 2010. 
We attempt to show the quantitative impact of particular shocks on the development of the Polish economy in 2009 by means of econometric simulations.

The ex-post simulations are based on the W8D macroeconometric model of the Polish economy, which has recently been used in performing long-term ex-ante simulations [Welfe, Florczak, 2009]. Its major properties are briefly described, and medium-term (baseline) forecasts are presented. However, these forecasts did not foresee the worldwide recession. We also summarize our first attempts to present the pessimistic outcomes of long-term scenarios, which, however, failed to predict the deep exports shocks that occurred in 2009; instead the scenarios suggested that investment would decline.

Next, the developments that took place in 2009 are analyzed. We show how international forecasts for that year changed from pessimistic to moderately optimistic. Then the results of ex-post scenarios for 2009 are demonstrated. The assumptions regarding the aforementioned shocks and the simulation results are presented, and the impact of individual shocks will be analyzed separately in order to show how the potential decline of domestic activities due to the exports shock was mitigated because of the zloty depreciation, domestic inertia and policy actions.

\section{Properties of the W8D simulation model}

The hypotheses presented in the introduction as to the impact of factors responsible for the slowdown of the Polish economy in 2009 are verified using a simulation version of the W8D-2007 macroeconometric model for the Polish economy. The model follows the mainstream tradition of macroeconomic modeling [Bodkin, Klein, Marwah, 1991], [Klein, Welfe, Welfe, 2004], where largescale econometric simulation models are generally used in forecasting as well as in economic policy simulations and valuations [Clemments, Hendry, 2000], [Whitley, 1994].

The model used in this research is a medium-sized complete model, covering demand, supply and financial flows. It shows factors that determine long-term growth, not only investment but also total factor productivity dependent on R\&D and human capital. Its latest version, W8D-2007, has 235 equations of which 111 are stochastic. The estimations were based on a sample ending in 2005. The simulation version is simultaneous and includes the major feedbacks, both static and dynamic, including multiplier and acceleration effects as well as inflationary spiral ${ }^{1}$.

The model has recently been used in long-term forecasting (until 2030) and in the first scenario analyses. This was preceded by detailed analyses of the model's multipliers [Welfe, Florczak, 2009]. The studies resulted in a minor

1 A complete description of the model's structure is provided in Welfe (ed.) [2009] and the simulations are described in detail in Welfe, Florczak [2009]. A summary in English was given in a paper by W. Welfe [2008]. 
correction of import equations (introducing the full impact of relative price changes). Besides, any discrepancies between actual and predicted values beyond the estimation sample have been eliminated on a permanent basis following the inflow of updated information by means of either parameters or constant term adjustments. We first demonstrate the medium-term forecasts until 2015, one of which is treated as a baseline for further investigations. The forecast was made before the first signs of the world recession appeared. It assumed that investment would decline, leading to a drop in GDP growth in 2009 (from 5\% to 2.5\%) - a trend expected to carry over into 2010. This forecast is demonstrated in Table 1 and Figures 1-3.

Table 1

Rates of growth for the Polish economy in 2006-2015 (baseline forecast), \%

\begin{tabular}{|l|r|r|r|r|r|r|r|}
\hline \multirow{2}{*}{ Category } & \multicolumn{9}{c|}{ Year } \\
\cline { 2 - 9 } & \multicolumn{1}{c|}{09} & 10 & 11 & 12 & 13 & 14 & 15 \\
\hline Private consumption & 3.1 & 3.4 & 3.8 & 4.0 & 3.6 & 3.5 & 3.3 \\
\hline Gross investments & 6.3 & 6.8 & 15.7 & 20.8 & 12.1 & 9.4 & 6.8 \\
\hline Gross investments (\% share in GDP) & 23.4 & 23.9 & 26.1 & 29.7 & 31.5 & 32.8 & 33.4 \\
\hline Exports & 5.3 & 7.5 & 7.5 & 8.5 & 10.0 & 9.2 & 11.2 \\
\hline Imports & 7.3 & 7.7 & 10.3 & 12.7 & 11.7 & 10.7 & 10.2 \\
\hline GDP & 2.5 & 4.0 & 5.6 & 6.2 & 5.1 & 4.5 & 4.3 \\
\hline Unemployment rate & 11.3 & 10.5 & 9.4 & 8.8 & 8.3 & 7.9 & 7.5 \\
\hline Private consumption deflator & 3.6 & 2.6 & 2.9 & 2.7 & 2.3 & 2.5 & 2.1 \\
\hline Exchange rate: \$/zl & 1.8 & 0.8 & -0.3 & 0.9 & 1.6 & 0.4 & -5.7 \\
\hline
\end{tabular}

Source: own computations

Figure 1. Domestic final demand and GDP (\% rates of growth)

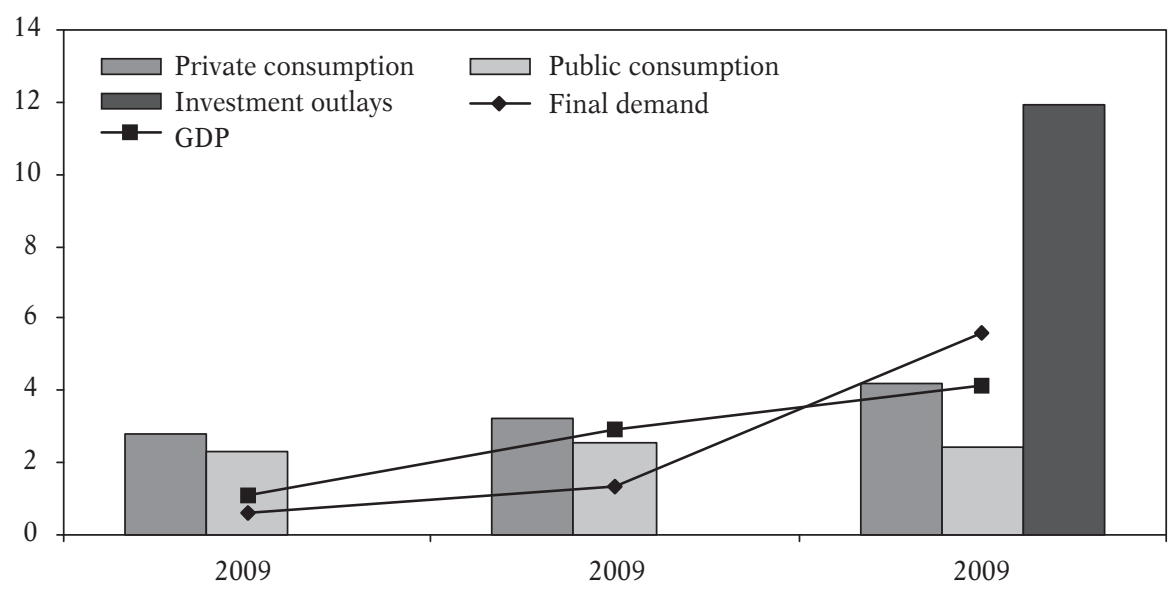

Source: own elaboration 
Figure 2. Foreign trade by national accounts (\% rates of growth)

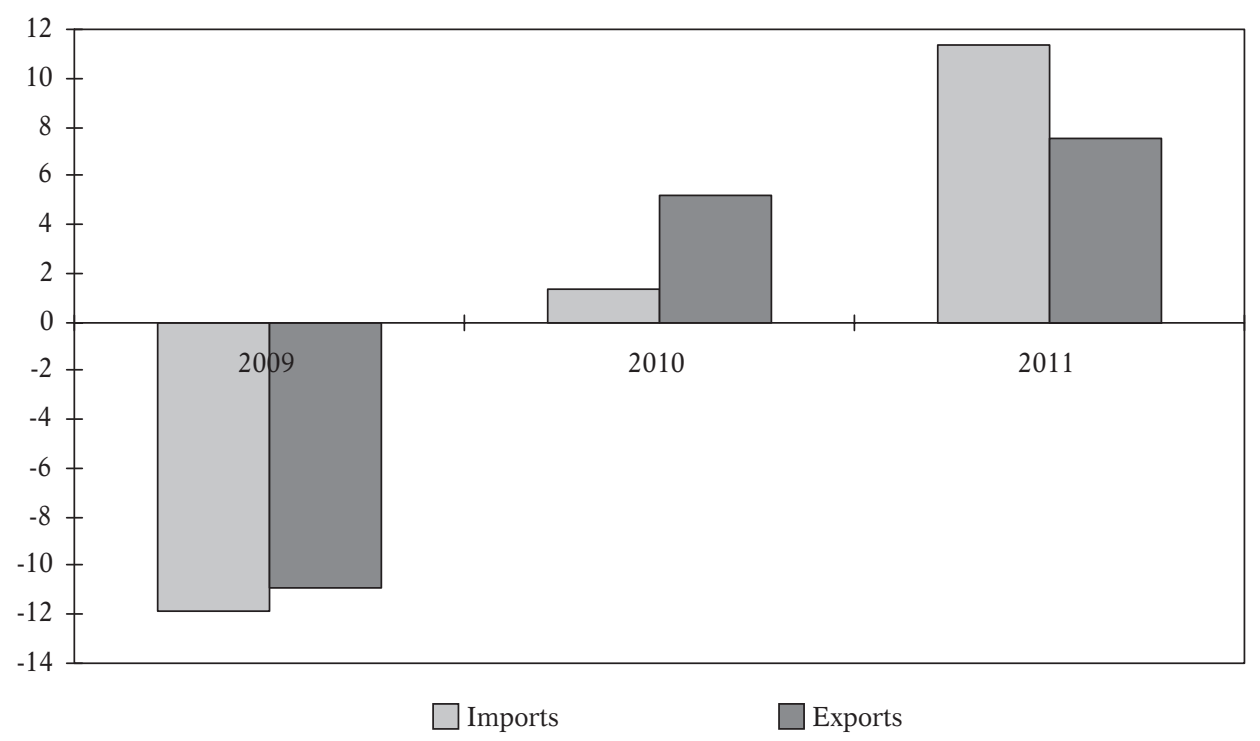

Source: own elaboration

Figure 3. Unemployment

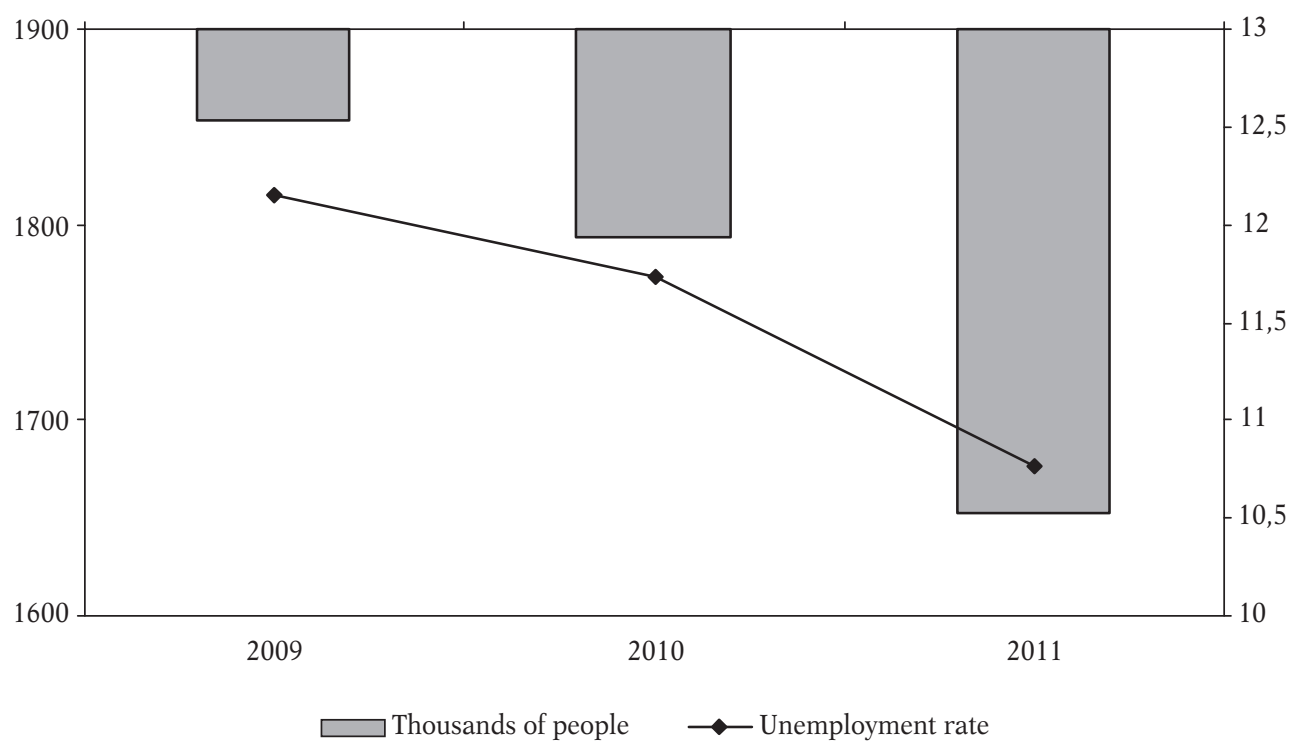

Source: own elaboration 


\section{First scenarios based on simulations}

The W8D-2007 model was used in experimental simulation exercises aimed at analyzing scenarios for the likely growth of the Polish economy until $2030^{2}$. The pessimistic scenarios assumed low rates of investment growth, i.e. a stagnation or decline in investment's contribution to the GDP, low FDI inflow and low transfers from the EU. The assumptions for the growth of exports were rather unrealistic. They were kept at 5\%. Only in the restrictive version were they equal to $3 \%$, but for the world recession we were unable to visualize a decline approaching 10\% in 2009. These assumptions are shown in Table 2.

Table 2

Assumptions for the scenarios of Poland's economic growth in 2010 and 2015

\begin{tabular}{|c|c|c|}
\hline \multirow{2}{*}{ Variable/scenario } & \multicolumn{2}{|c|}{ Year } \\
\hline & 2010 & 2015 \\
\hline Share of investment outlays in GDP (\%) & & \\
\hline optimistic & 26.5 & 35.0 \\
\hline baseline & 23.9 & 33.4 \\
\hline pessimistic & 22.0 & 20.0 \\
\hline world recession & 22.0 & 19.5 \\
\hline restrictive & 20.0 & 15.5 \\
\hline Share of FDI in GDP (\%) & & \\
\hline optimistic & 4.2 & 4.0 \\
\hline baseline & 3.1 & 2.8 \\
\hline pessimistic & 0.4 & 1.4 \\
\hline world recession & 0.4 & 1.4 \\
\hline restrictive & 0.4 & 1.5 \\
\hline Share of net transfers from the EU in GDP (\%) & & \\
\hline optimistic & 3.5 & 3.2 \\
\hline baseline & 3.5 & 3.2 \\
\hline pessimistic & 3.5 & 3.2 \\
\hline world recession & 2.5 & 2.2 \\
\hline restrictive & 2.5 & 2.2 \\
\hline Rates of growth for exports & & \\
\hline optimistic & 10.0 & 12.0 \\
\hline baseline & 7.5 & 11.2 \\
\hline pessimistic & 5.0 & 5.0 \\
\hline world recession & 5.0 & 5.0 \\
\hline restrictive & 3.0 & 3.0 \\
\hline
\end{tabular}

Source: own computations

2 The assumptions were made at the end of 2008; the same is true of the simulations listed in Table 2. 
The results for the pessimistic scenarios are shown in Table 3 and for the world recession scenario in Table 4 and Figures 4-8. Despite an erroneous assumption for exports, the rate of GDP growth in 2009 (at 1.5\%) was close to the observed one (at 1.7\%). Domestic demand helped the country avoid a recession. Developments in the following years showed a pessimistic picture resulting from the assumption that the world recession would continue for many years.

Table 3

Pessimistic scenario; rates of growth and deviations from the baseline in 2009-2015

\begin{tabular}{|l|r|r|r|r|r|r|r|}
\hline \multirow{2}{*}{ Category } & \multicolumn{7}{c|}{ Year } \\
\cline { 2 - 8 } & \multicolumn{1}{|c|}{09} & \multicolumn{1}{c|}{10} & \multicolumn{1}{c|}{11} & \multicolumn{1}{c|}{12} & \multicolumn{1}{c|}{13} & \multicolumn{1}{c|}{14} & \multicolumn{1}{c|}{15} \\
\hline Private consumption & 3.27 & 0.94 & 0.49 & -0.82 & -0.44 & 0.25 & 0.28 \\
\hline \% deviations & 0.14 & -2.28 & -5.43 & -9.85 & -13.4 & -16.1 & -18.6 \\
\hline Gross investments & -0.05 & -0.08 & -2.75 & -3.25 & -5.19 & -3.28 & -3.45 \\
\hline$\%$ deviations & -5.97 & -12 & -26.1 & -40.8 & -49.9 & -55.7 & -60 \\
\hline Gross investments (\% share in GDP) & 22.47 & 22.19 & 21.36 & 20.65 & 19.57 & 18.93 & 18.46 \\
\hline$\%$ deviations & -0.89 & -1.66 & -4.76 & -9.02 & -12 & -13.9 & -15 \\
\hline Exports & 5 & 5 & 5 & 5 & 5 & 5 & 5 \\
\hline$\%$ deviations & -0.24 & -2.57 & -4.86 & -7.94 & -12.1 & -15.5 & -20.2 \\
\hline Imports & 5.75 & 2.6 & 1.88 & 2.18 & 4.68 & 7.13 & 6.61 \\
\hline$\%$ deviations & -1.44 & -6.12 & -13.3 & -21.4 & -26.3 & -28.7 & -31.1 \\
\hline GDP & 1.54 & 1.69 & 0.99 & -0.7 & -1.51 & -1.45 & -2.18 \\
\hline$\%$ deviations & -0.89 & -3.11 & -7.29 & -13.3 & -18.8 & -23.4 & -28.2 \\
\hline Unemployment rate & 10.65 & 9.97 & 10.23 & 11.43 & 12.72 & 14.03 & 15.52 \\
\hline$\%$ deviations & -0.6 & -0.51 & 0.78 & 2.61 & 4.45 & 6.14 & 8.05 \\
\hline Private consumption deflator & 0.34 & 0.7 & 0.09 & 0.67 & 0.91 & 0.79 & 0.1 \\
\hline$\%$ deviations & -3.13 & -4.94 & -7.56 & -9.37 & -10.6 & -12.1 & -13.8 \\
\hline Exchange rate: \$/zl & 4.1 & 0.03 & -5.58 & -6.35 & -5.81 & -4.2 & -2.49 \\
\hline$\%$ deviations & 2.31 & 1.56 & -3.85 & -10.8 & -17.3 & -21.1 & -22.9 \\
\hline
\end{tabular}

Source: own computations

Table 4

World recession scenario; rates of growth and deviations from the baseline in 2009-2015

\begin{tabular}{|l|c|c|c|c|c|c|c|}
\hline \multirow{2}{*}{\multicolumn{1}{|c|}{ Category }} & \multicolumn{7}{|c|}{ Year } \\
\cline { 2 - 8 } & 09 & 10 & 11 & 12 & 13 & 14 & 15 \\
\hline Private consumption & 3.27 & 0.94 & -1.14 & -3.48 & -3.96 & -3.37 & -4.15 \\
\hline$\%$ deviations & 0.14 & -2.28 & -6.96 & -13.7 & -20 & -25.3 & -30.7 \\
\hline Gross investments & -0.05 & -0.08 & -2.75 & -3.25 & -5.18 & -3.25 & -3.42 \\
\hline$\%$ deviations & -5.97 & -12 & -26.1 & -40.8 & -49.9 & -55.7 & -59.9 \\
\hline $\begin{array}{l}\text { Gross investments } \\
\text { (\% share in GDP) }\end{array}$ & 22.47 & 22.19 & 21.49 & 20.98 & 20.13 & 19.69 & 19.49 \\
\hline
\end{tabular}


continued Table 4

\begin{tabular}{|l|r|r|r|r|r|r|r|}
\hline \multirow{2}{*}{ Category } & \multicolumn{7}{|c|}{ Year } \\
\cline { 2 - 8 } & \multicolumn{1}{|c|}{09} & 10 & 11 & \multicolumn{1}{c|}{12} & \multicolumn{1}{c|}{13} & \multicolumn{1}{c|}{14} & \multicolumn{1}{c|}{15} \\
\hline \% deviations & -0.89 & -1.66 & -4.63 & -8.69 & -11.4 & -13.1 & -14 \\
\hline Exports & 5 & 5 & 5 & 5 & 5 & 5 & 5 \\
\hline$\%$ deviations & -0.24 & -2.57 & -4.86 & -7.94 & -12.1 & -15.5 & -20.2 \\
\hline Imports & 5.75 & 2.6 & 0.81 & 0.55 & 2.85 & 5.69 & 5.03 \\
\hline$\%$ deviations & -1.44 & -6.12 & -14.2 & -23.5 & -29.5 & -32.7 & -35.9 \\
\hline GDP & 1.54 & 1.69 & 0.34 & -1.78 & -3 & -3.06 & -4.2 \\
\hline$\%$ deviations & -0.89 & -3.11 & -7.89 & -14.8 & -21.4 & -27.1 & -33.1 \\
\hline Unemployment rate & 10.65 & 9.97 & 10.29 & 11.62 & 13.12 & 14.68 & 16.47 \\
\hline$\%$ deviations & -0.6 & -0.51 & 0.84 & 2.81 & 4.85 & 6.79 & 9 \\
\hline $\begin{array}{l}\text { Private consumption } \\
\text { deflator }\end{array}$ & 0.34 & 0.7 & 0.09 & 0.67 & 0.91 & 0.79 & 0.1 \\
\hline$\%$ deviations & -3.13 & -4.94 & -7.56 & -9.37 & -10.6 & -12.1 & -13.8 \\
\hline Exchange rate: $\$$ /zl. & 4.1 & 0.03 & -5.62 & -7.07 & -6.99 & -5.59 & -3.7 \\
\hline$\%$ deviations & 2.31 & 1.56 & -3.89 & -11.5 & -19 & -23.9 & -26.5 \\
\hline
\end{tabular}

Source: own computations

Figure 4. GDP, rates of growth (left axis) and \% deviations from baseline (right axis)

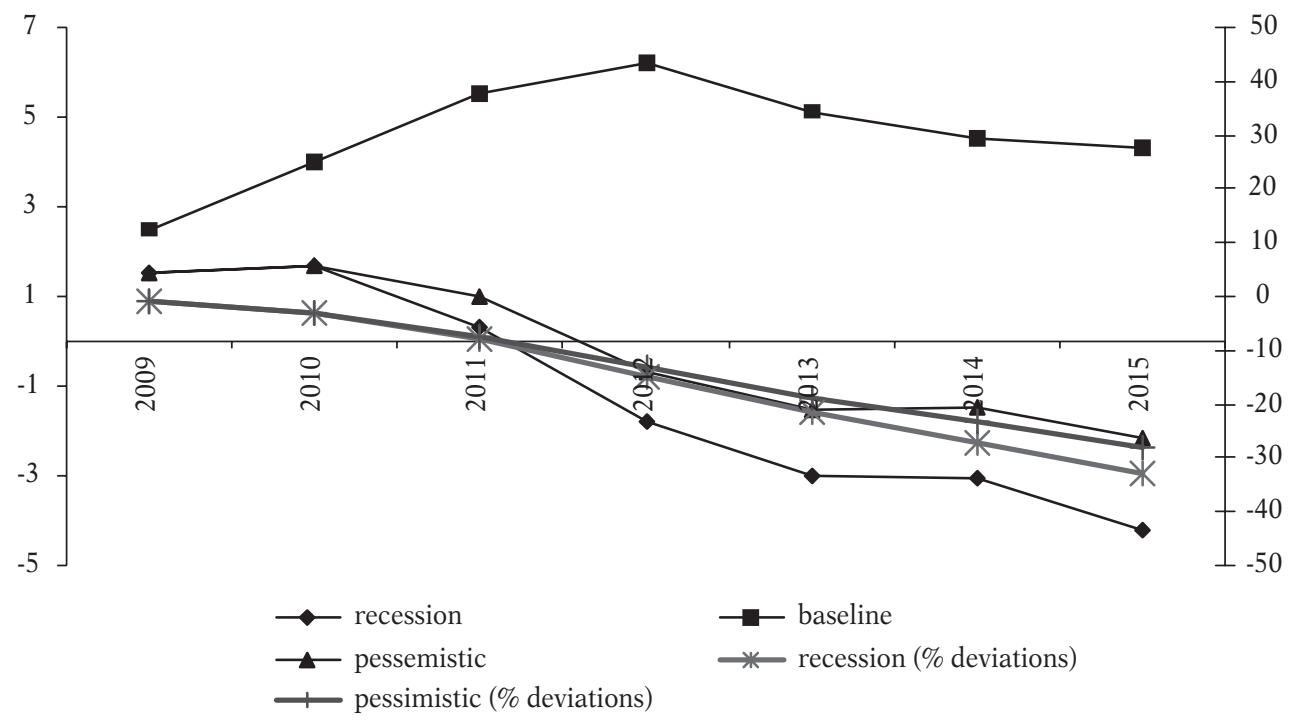

Source: own elaboration 
Figure 5. Private consumption, rates of growth (left axis) and \% deviations from baseline (right axis)

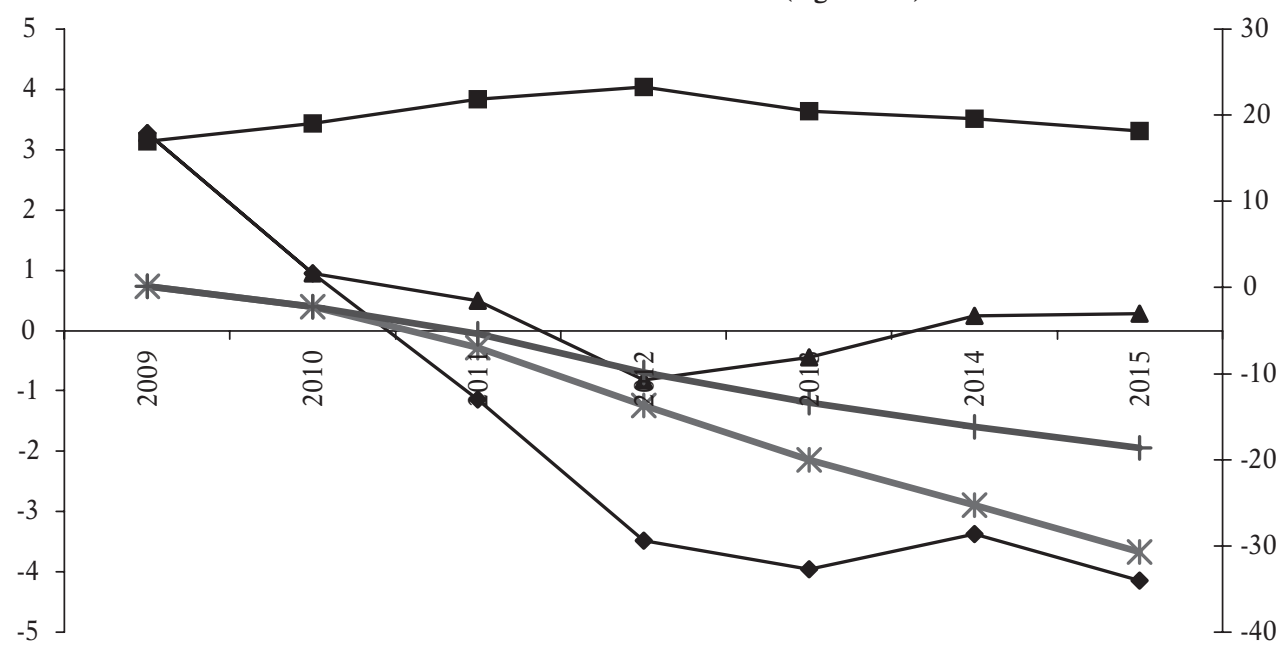

$\longrightarrow$ recession
$\leftarrow$ pessimistic
$\square$ pessimictic (\% deviations)

$\longrightarrow$ - baseline
$\rightarrow-$ recession (\% deviations)

Source: own elaboration

Figure 6. Investment outlays, rates of growth (left axis) and \% deviations from baseline (right axis)

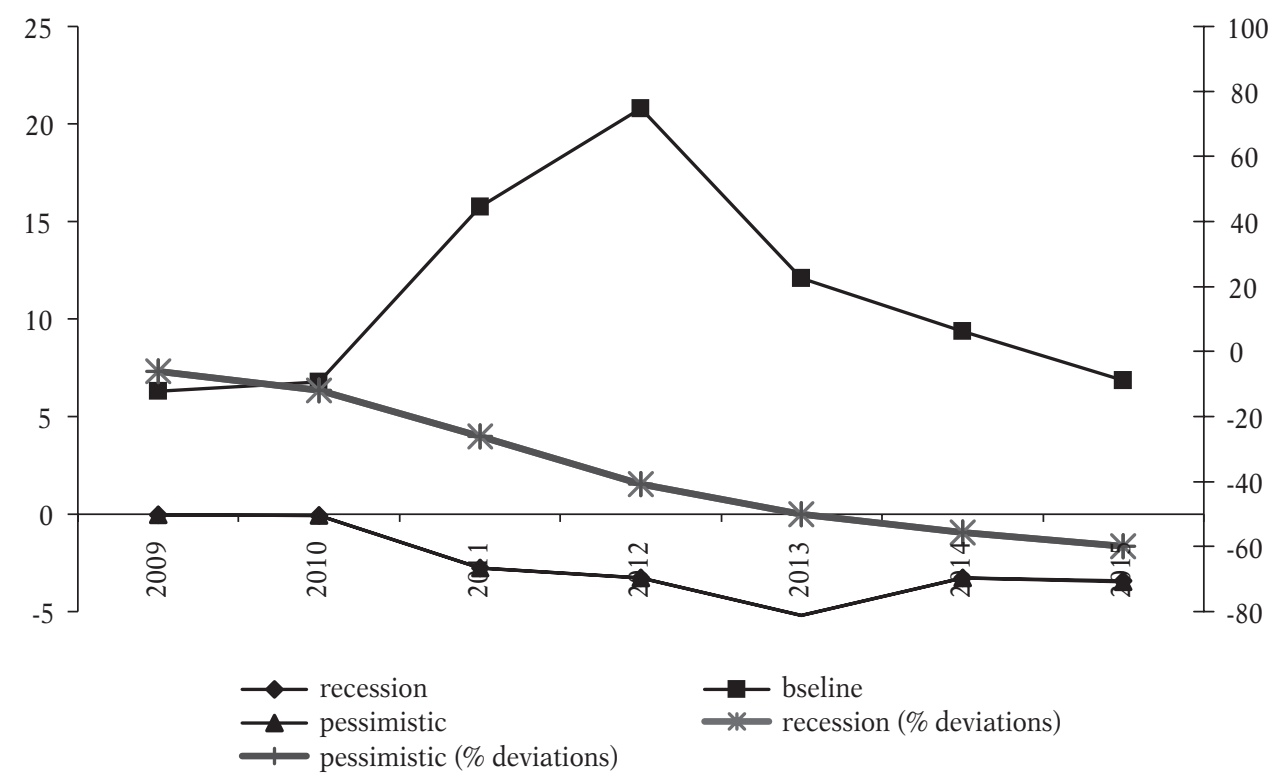

Source: own elaboration 
Figure 7. Imports, rates of growth (left axis) and \% deviations from baseline (right axis)

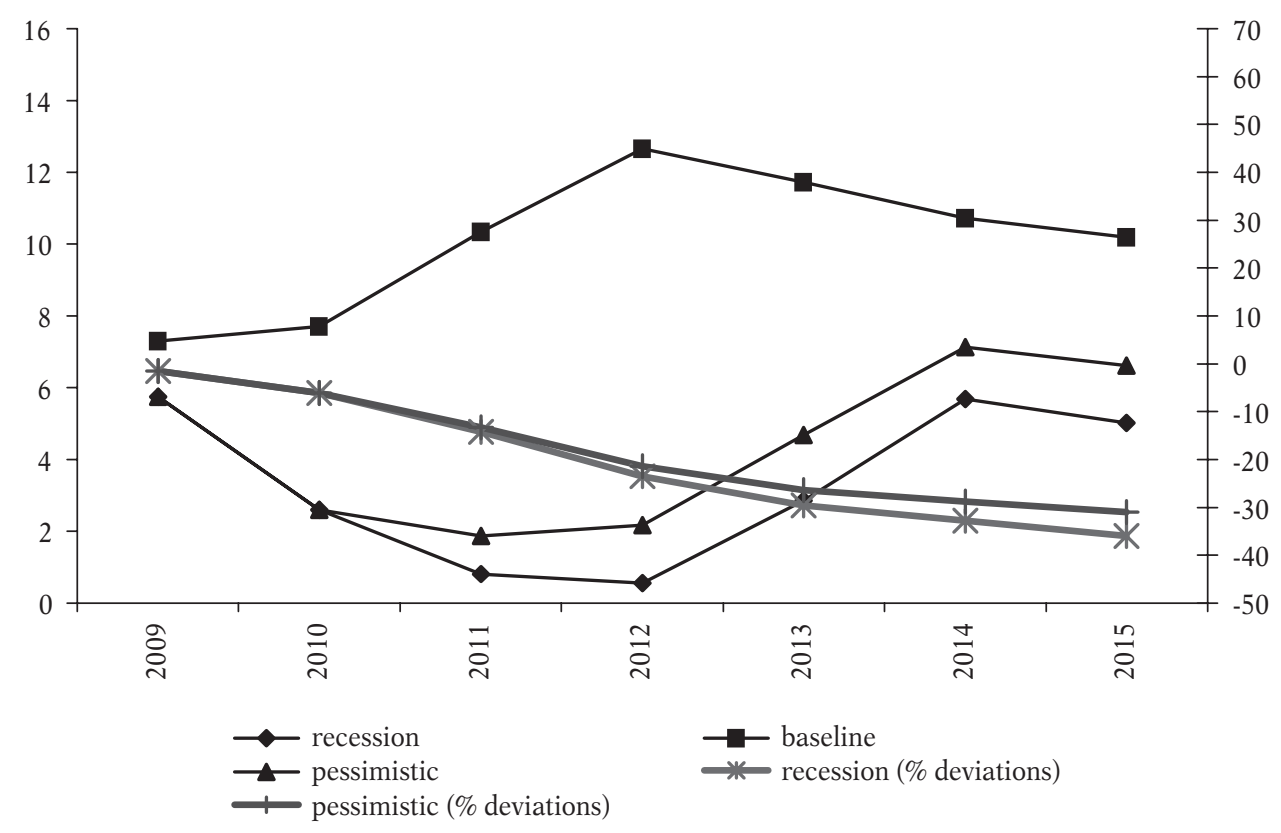

Source: own elaboration

Figure 8. Unemployment rate

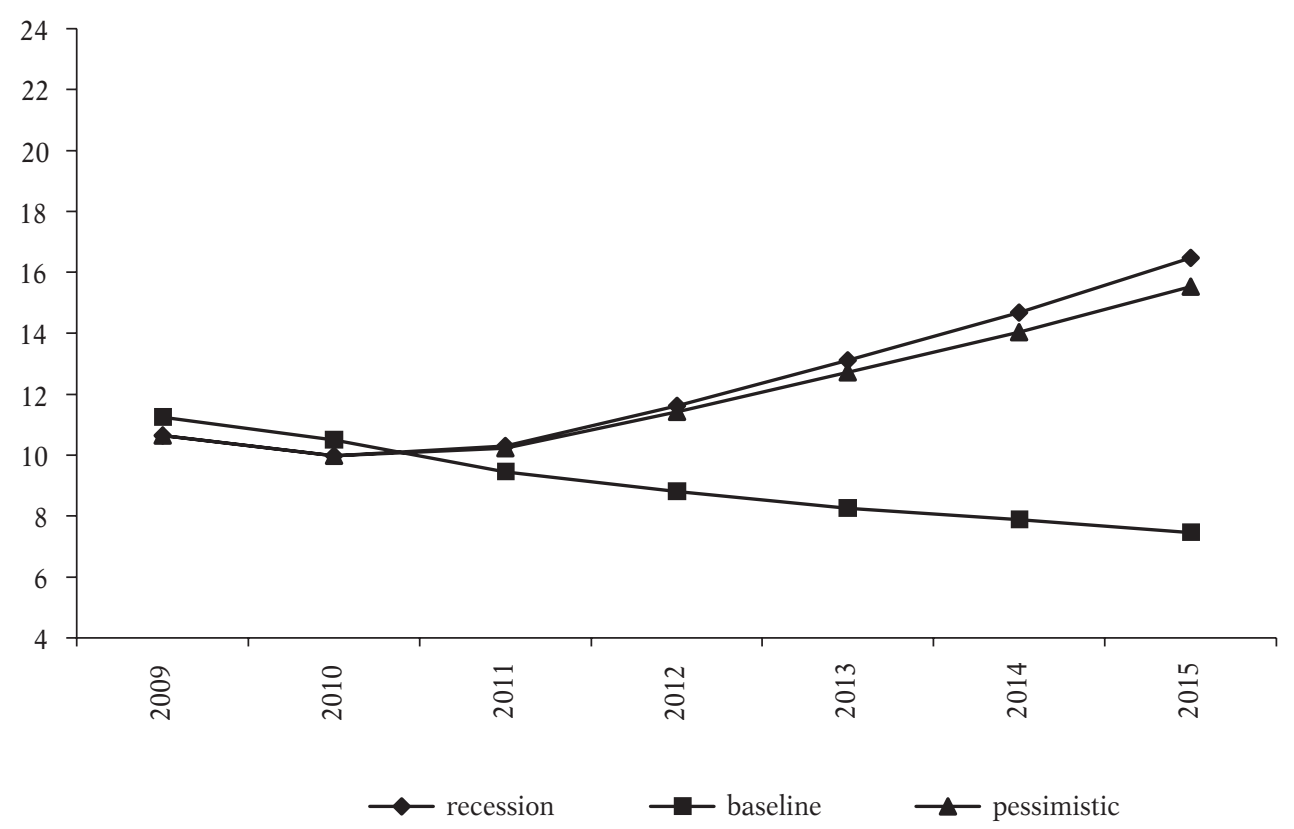

Source: own elaboration 


\section{An evaluation of forecasts for the Polish economy for 2009}

By the end of 2008 there was a general uncertainty in the world forecasting community as to the future development of industrial countries, including Poland. The evolution of GDP forecasts will be shown below (Table 5), taking into account information based on our quarterly and annual forecasts using WK and W8D models as well as data provided by Consensus Forecasts showing the forecasts of private forecasting organizations (mainly banks) and international institutions.

Table 5 contains information on the actual rates of GDP growth by quarter (cumulative) that help explain changes in forecasts during 2009.

Table 5

Rates of growth for the Polish economy in 2009

\begin{tabular}{|c|c|c|c|c|c|}
\hline & \multicolumn{5}{|c|}{$\begin{array}{c}\text { Average } \% \\
\text { Change on previous calendar year }\end{array}$} \\
\hline & \multirow[b]{2}{*}{2008} & \multicolumn{4}{|c|}{2009} \\
\hline & & up to March & up to June & $\begin{array}{c}\text { up to } \\
\text { September }\end{array}$ & year total \\
\hline Registered change & 5.0 & 0.8 & 1.0 & 1.2 & 1.7 \\
\hline Forecasts 2009 & end 2008 & March 2009 & June 2009 & $\begin{array}{l}\text { September } \\
2009\end{array}$ & $\begin{array}{l}\text { December } \\
2009\end{array}$ \\
\hline LIFEA quarterly & 4.0 & 1.0 & 0.7 & 1.2 & 1.3 \\
\hline LIFEA LINK annual & . & . & 1.0 & 1.1 & . \\
\hline LIFEA Consensus & 3.3 & 1.0 & 0.9 & 1.0 & 1.5 \\
\hline CONSENSUS (mean) & 1.9 & 0.1 & 0.1 & 1.0 & 1.5 \\
\hline EBRD & $2.8^{a)}$ & 0.0 & 0.0 & 0.0 & $1.3 \mathrm{~d})$ \\
\hline EC & 2.0 & -1.4 & $-1.4 \mathrm{c})$ & $\left.-1.4^{b}\right)$ & $1.2^{\mathrm{d})}$ \\
\hline IMF & $3.8^{a)}$ & -0.7 & $-0.7^{b)}$ & $-0.7 \mathrm{c})$ & $1.0^{\mathrm{a})}$ \\
\hline OECD & 3.0 & 3.0 & -0.4 & -0.4 & $1.4^{\mathrm{a})}$ \\
\hline World Bank & 2.3 & 0.5 & $\left.0.5^{c}\right)$ & 0.5 & 1.3 \\
\hline
\end{tabular}

a) October 2008, b) April, c) May, d) October, e) November 2009

Source: Consensus Forecasts, different numbers, LIFEA reports

Until the end of 2008, forecasting institutions predicted a decline in Poland's GDP growth rate from 5\% to $2 \%-3 \%$ in 2009 . A slowdown was generally predicted, but not a recession. The shock in exports (a decline by 16\%) in the first quarter of 2009, associated with a decline in the rate of GDP growth to $0.8 \%$, dramatically changed expectations about 2009 as a whole. We still predicted a growth by $1 \%$, while most forecasters expected either stagnation or recession (a 1.4\% drop, according to the European Commission). The "optimistic" data on (cumulative) GDP growth in the following quarters encouraged domestic forecasters to increase the expected annual GDP growth rates to $1 \%-1.2 \%$. At the end of the year general forecasts became more optimistic. No forecaster 
expected a recession but all forecasts were generally below the achieved $1.7 \%$ rate of growth.

Generally, one may conclude that the world community underestimated the expected GDP growth rates for the Polish economy.

\section{Ex-post simulation assumptions}

The hypotheses presented in the introduction as to the impact of factors affecting the slowdown of the Polish economy in 2009 are verified, making use of the W8D simulation macroeconometric model for the Polish economy.

A detailed analysis of the model's multipliers preceded the simulation exercises. This primarily applied to variables that were subject to shocks by the end of 2008 or the beginning of 2009. They are shown below with the values of the assumed shocks.

International environment

- Decreased international demand for Polish commodities: exports down by $11 \%$

- FDI decrease: down by $15 \%$

Prices

- zl./\$ exchange rate: zloty losing $20 \%$ against the dollar to trade at 2.91, from 2.42

- Constrained impact of imports prices on CPI by 4 p.p.

Fiscal policy

- Reduction in income taxes and social contribution rates: 6\% increase in disposable income

- Increase of the budget deficit, i.e. of government expenditures, by zl 9 billion, or around $50 \%$, in the middle of the year

Monetary policy

- Decline of the basic interest rate from $5.0 \%$ to $3.5 \%$.

The results of simulation exercises will take as a point of departure our baseline forecast for 2009 as shown in Welfe, Florczak [2009]. The rates of growth assumed the expected levels of particular variables in 2008 predicted in that forecast. They were used as a point of reference for the updated forecasts based on the ex-post simulations.

We present the simulation results step by step, beginning with the exogenous shocks in world trade and following up with the results of further shocks and the expected results of government interventions, taking into account the ad hoc adjustments of households and firms. At the end, we summarize the obtained results, assessing the appropriate role to be assigned to particular factors that protected the Polish economy from a recession. The results are presented in consecutive tables with comments where necessary ${ }^{3}$.

3 All the simulation experiments were performed by W. Florczak. 
Tables 6-8 show the simulation results obtained in the abovementioned order. The results shown in consecutive columns report the cumulative effect of all the previous shocks.

\section{The impact of the exports decline and the exchange rate increase}

The isolated impact of the export shock is dramatic. The decreased activity of export industries is followed by a decline in industries producing intermediate commodities as well as by a decrease in employment, real incomes and consumption and also in investment outlays related to slower GDP growth (Table 6).

The total decline of final demand would amount to around $8 \%$. Imports would decline by nearly 13\%, hence the GDP drop might be around $8.5 \%$. Employment would seriously decline and the unemployment rate would increase considerably. The shock did not affect the inflation rates. They would decline slightly because of a decrease in the exchange rate causing exports to decline more deeply than imports.

The situation would change for the better due to an unexpected $20 \%$ increase in exchange rates at the end of 2008 (in annual terms).

Table 6

Percentage rates of growth in 2009 after an export shock and an exchange rate increase

\begin{tabular}{|c|c|c|c|c|c|}
\hline \multirow{3}{*}{ Category } & \multirow{3}{*}{ Baseline } & \multicolumn{3}{|c|}{ Impact of } & \multirow{3}{*}{ Observed } \\
\hline & & \multirow{2}{*}{$\begin{array}{l}\text { exports } \\
\text { decline }\end{array}$} & \multicolumn{2}{|c|}{ exchange rate increase } & \\
\hline & & & initial & adjusted & \\
\hline Private consumption & 3.1 & -5.5 & -1.6 & -0.1 & 2.3 \\
\hline Gross investment & 6.3 & -10.9 & 2.3 & 1.9 & -0.3 \\
\hline Domestic final demand & 3.4 & -7.7 & -1.1 & -0.9 & -0.9 \\
\hline GDP & 2.5 & -8.3 & 0.6 & 0.1 & 1.7 \\
\hline Exports & 7.5 & -11.0 & -9.8 & -9.9 & -7.5 \\
\hline Imports & 8.0 & -9.6 & -13.0 & -11.6 & -12.0 \\
\hline Labor productivity & 3.4 & -2.8 & 2.6 & 2.3 & . \\
\hline Labor demand & -0.9 & -5.7 & -1.9 & -2.1 & . \\
\hline Unemployment rate $\%$ b) & 11.3 & . & & 13.7 & 11.9 \\
\hline Nominal wages & 5.8 & -5.1 & 7.8 & 4.9 & 3.7 \\
\hline Real disposable income & 1.9 & -9.1 & -1.7 & -1.3 & . \\
\hline GDP deflator & 3.9 & 2.3 & 0.5 & 2.5 & . \\
\hline CPI & 3.6 & 2.3 & 5.9 & 3.2 & 3.3 \\
\hline Exchange rate: $\mathrm{zl} / \$ \mathrm{a})$ & 2.9 & 2.8 & 2.9 & 2.9 & 2.83 \\
\hline Interest rate ${ }^{b)}$ & 6.1 & 5.7 & 7.3 & 6.5 & 3.75 \\
\hline
\end{tabular}

a) nominal value b) percentage level

Source: own computations 
Exporters would be confident that their profits would increase to partly compensate for losses incurred from the exports decline; they would be unlikely to compete by reducing dollar-denominated prices. Hence, the decline of exports would be 1 percentage point lower (being close to -10\%). Imports, being highly price sensitive, would show a much bigger additional decline of up to $13 \%$, yielding a considerable addition to net exports.

This to a large extent explains why a considerable increase in GDP would take place despite a $1 \%$ decrease in total domestic final demand.

As the transmission of the exchange rate increase into retail prices was blocked by trade organizations (which treated it as temporary), the respective adjustment of the CPI reduced the decline in private consumption from $1.6 \%$ to nearly zero. At the same time, commodity imports were adjusted upward, while GDP growth was revised downward.

The above adjustments helped keep the inflation rates at low levels.

\section{The effects of economic policy interventions}

Economic policy measures had a positive impact on what happened in the economy. Monetary policymakers decided to reduce the principal interest rate many times during 2009. Commercial banks responded with some delay. Even though that response was limited to new loans, its net impact was positive. Private consumption increased by nearly 1 p.p. and investments by 0.7 p.p., which resulted in an increase of GDP by 0.4 p.p. (see Table 7).

The decrease in tax rates and the social contribution rate in 2007-2008 had a much stronger effect. It increased real disposable income by an estimated 3 p.p. and private consumption by up to $2.5 \%$. The multiplier effects were substantial, leading to a $1.6 \%$ increase in final domestic demand. In all, the GDP increase amounted to $1.5 \%$. The decline of employment was less pronounced and unemployment remained high at $13.3 \%$. Prices were not affected by the aforementioned demand pressures (Table 7).

Another fiscal policy instrument was used in mid-2009 when the parliament increased the budget deficit. This prevented budget expenditures from declining further. As a result of this move, social consumption grew after a prolonged decline. As a result, the GDP growth rate went up to $1.7 \%$.

Table 7

Percentage rates of growth in 2009 after economic policy interventions

\begin{tabular}{|c|c|c|c|c|}
\hline \multirow{3}{*}{ Category } & \multicolumn{3}{|c|}{ Additional impact of } & \multirow{3}{*}{ Observed } \\
\hline & \multicolumn{2}{|c|}{ decrease } & \multirow{2}{*}{$\begin{array}{l}\text { increase of budget } \\
\text { expenditures }\end{array}$} & \\
\hline & in interest rates & in personal taxes & & \\
\hline Private consumption & 0.7 & 2.5 & 2.5 & 2.3 \\
\hline Social consumption & -5.1 & -3.5 & 2.3 & . \\
\hline Gross investment & 2.6 & 4.2 & 4.6 & -0.3 \\
\hline
\end{tabular}


continued Table 7

\begin{tabular}{|c|c|c|c|c|}
\hline \multirow{3}{*}{ Category } & \multicolumn{3}{|c|}{ Additional impact of } & \multirow{3}{*}{ Observed } \\
\hline & \multicolumn{2}{|c|}{ decrease } & \multirow{2}{*}{$\begin{array}{c}\text { increase of budget } \\
\text { expenditures }\end{array}$} & \\
\hline & in interest rates & in personal taxes & & \\
\hline Domestic final demand & -0.2 & 1.6 & 1.8 & -0.9 \\
\hline GDP & 0.5 & 1.5 & 1.7 & 1.7 \\
\hline Exports & -9.9 & -9.9 & -9.9 & -7.5 \\
\hline Imports & -11.1 & -9.5 & -9.3 & -12.0 \\
\hline Labor productivity & 2.5 & 3.1 & 3.2 & 1.9 \\
\hline Labor demand & -2.0 & -1.6 & -1.4 & -0.2 \\
\hline Unemployment rate $\%$ b) & 13.6 & 13.3 & 13.1 & 11.9 \\
\hline Nominal wages & 5.3 & 6.4 & 6.2 & 3.7 \\
\hline Real disposable income & 0.1 & 2.6 & 2.3 & 2.0 \\
\hline GDP deflator & 2.6 & 2.8 & 2.8 & 3.0 \\
\hline CPI & 3.2 & 3.2 & 3.2 & 3.3 \\
\hline Exchange rate: $\mathrm{zl} / \$ \mathrm{a})$ & 2.9 & 2.9 & 2.1 & 2.93 \\
\hline Interest rate ${ }^{\mathrm{b})}$ & 3.8 & 3.8 & 3.9 & 3.75 \\
\hline
\end{tabular}

a) nominal value b) percentage level

Source: own computations

\section{Final adjustments}

Investment suffered due to an increase in investment risk associated with a pessimistic outlook for future output. That was especially manifested by a decline in foreign direct investment. The estimates of an additional shock resulting in a FDI decline are given in Table 8. Investment outlays would decline by less than $1 \%$ (close to the observed value). The end result is to some extent surprising as the majority of forecasters predicted a serious decline in investment. In fact, started investment projects were continued without major interruptions as could be seen from an increase in building activities over 2009 .

The decline of the growth rates was followed by a decline in labor demand and, with some delay, by an increase in the unemployment rate. Action taken by government institutions in the labor market made the demand adjustments much slower and less pronounced than the model's prediction. This explains why we introduced a change in the lags in the labor demand equation. That resulted in a decline in the unemployment rate from $13 \%$ to nearly $12 \%$ (Table 8).

At the end of our simulation exercises we arrived at new statistical information, showing that the decline in exports was not as deep as we initially assumed, but the imports decline was deeper. The resulting adjustments are shown in Table 8 . 


\section{Simulation summary and a final note}

Model simulations helped us assess the quantitative impact of factors responsible for the slowdown of the Polish economy in 2009. This slowdown, as measured by the difference from the baseline forecasts (2.5\% GDP growth rate) to the actual $1.7 \%$ rate of GDP growth in 2009, may seem negligible as compared with the recessions in other European countries. It is interesting, however, to show how the external shocks - similar to those recorded in neighboring countries - have been mitigated in Poland.

Table 8

Percentage rates of growth in 2009 after final adjustments

\begin{tabular}{|c|c|c|c|c|}
\hline \multirow[b]{2}{*}{ Category } & \multicolumn{3}{|c|}{ Additional impact } & \multirow[b]{2}{*}{ Observed } \\
\hline & of FDI decline & $\begin{array}{c}\text { of extending } \\
\text { lags in labor } \\
\text { demand decline }\end{array}$ & $\begin{array}{l}\text { of foreign trade } \\
\text { adjustments }\end{array}$ & \\
\hline Private consumption & 1.6 & 2.3 & 2.3 & 2.3 \\
\hline Government consumption & 1.2 & 1.4 & 1.4 & 1.3 \\
\hline Gross investment & -0.3 & -0.4 & -0.4 & -0.3 \\
\hline Domestic final demand & -0.1 & -0.9 & -0.9 & -0.9 \\
\hline GDP & 0.6 & 1.7 & 1.7 & 1.7 \\
\hline Exports & -9.9 & -7.6 & -7.6 & -7.5 \\
\hline Imports & -10.9 & -12.2 & -12.2 & -12.0 \\
\hline Labor productivity & 2.6 & 0 & 3.2 & 1.9 \\
\hline Labor demand & -1.9 & 1.7 & -1.4 & -0.2 \\
\hline Unemployment rateb) & 13.3 & 11.4 & 13.1 & 11.9 \\
\hline Nominal wages & 5.3 & 2.3 & 6.3 & 3.7 \\
\hline Real disposable income & 1.2 & 2.3 & 2.3 & 2.0 \\
\hline GDP deflator & 2.7 & 3.9 & 2.7 & 3.0 \\
\hline CPI & 3.2 & 3.2 & 3.2 & 3.3 \\
\hline Exchange rate: $\mathrm{zl} / \$ \mathrm{a})$ & 2.9 & 2.9 & 2.9 & 2.93 \\
\hline Interest rateb) & 4.0 & 3.9 & 3.9 & 3.75 \\
\hline
\end{tabular}

a) nominal value b) percentage level

Source: own computations

The external shocks alone leading to a serious decline in exports and FDI would have decreased the GDP growth rate by 10.8 p.p. so that the rate would have been $-8.3 \%$.

One external shock that definitely helped improve the situation was a devaluation of the zloty at the end of 2008. It brought about a deep decline in imports and an increase in GDP by 8 p.p., which would ensure a $0.1 \%$ rate of GDP growth. 
The increase in the GDP growth rate of up to $1.7 \%$ can be attributed to a combination of monetary policy effects (decline of interest rates), fiscal policy (income tax decrease and budget deficit increase), interventions in the labor market, and the behavior of consumers (habit persistence) and firms (competitiveness and lags in adjustments). All these factors contributed to an increase in GDP growth rates by another 1.6 p.p., which eventually resulted in a $1.7 \%$ rate of GDP growth.

It is worth noting that the manufacturing sector suffered from the exports decline, whereas the building industry showed a considerable increase, and the large services sector grew all the time. Both these sectors are heavily dependent on domestic demand.

The simulations exercises helped explain why the inflation rates remained unaffected by the zloty depreciation, and why the unemployment rates increased only slightly.

The above results also explain why the Polish government was not forced to engage public funds in rescue packages modeled after those introduced in Western countries. Nevertheless, the budget deficit target for 2010 was raised twice to zl 52.2 billion. This shows that the Polish authorities will not escape from the problem of rising domestic debt in the near future.

The slowdown of 2009 will have several repercussions in the years to follow. The recovery of final domestic demand has been postponed, especially in 2010 . Foreign trade seems to have recovered quickly. Hence, the GDP growth rate was estimated at $3 \%$ instead of $4 \%$ in 2010 , whereas in the following years it is expected to be 1 p.p. lower than in the baseline. The worst situation seems to prevail in the labor market where the unemployment rate remains close to 12\% (see Table 9; for details see Welfe W. [2009b]).

Table 9

Rates of growth for the Polish economy in 2008-2011 (baseline B) versus updated (U) forecast

\begin{tabular}{|l|r|r|r|r|r|r|r|r|}
\hline \multirow{2}{*}{ Category/Variant } & \multicolumn{9}{|c|}{ Year } \\
\cline { 2 - 10 } & \multicolumn{2}{|c|}{2009} & \multicolumn{2}{c|}{2010} & \multicolumn{2}{c|}{2011} & \multicolumn{2}{c|}{2012} \\
\cline { 2 - 10 } & \multicolumn{1}{|c}{$\mathrm{B}$} & \multicolumn{1}{c|}{$\mathrm{U}$} & \multicolumn{1}{c|}{$\mathrm{B}$} & \multicolumn{1}{c|}{$\mathrm{U}$} & \multicolumn{1}{c|}{$\mathrm{B}$} & \multicolumn{1}{c|}{$\mathrm{U}$} & \multicolumn{1}{c|}{$\mathrm{B}$} & \multicolumn{1}{c|}{$\mathrm{U}$} \\
\hline Private consumption & 3.1 & 2.3 & 3.4 & 2.6 & 3.8 & 2.7 & 4.0 & 3.1 \\
\hline Gross investments & 6.3 & -0.4 & 6.8 & 4.5 & 15.7 & 14.9 & 20.8 & 17.5 \\
\hline Gross investments (share in GDP) & 23.4 & 21.4 & 23.9 & 21.4 & 26.1 & 23.2 & 29.7 & 25.6 \\
\hline Exports & 5.3 & -7.6 & 7.5 & 7.2 & 7.5 & 7.6 & 8.5 & 8.6 \\
\hline Imports & 7.3 & -12.2 & 7.7 & 6.9 & 10.3 & 9.6 & 12.7 & 11.0 \\
\hline GDP & 2.5 & 1.7 & 4.0 & 3.0 & 5.6 & 4.7 & 6.2 & 5.2 \\
\hline Unemployment rate & 11.3 & 11.4 & 10.5 & 11.7 & 9.4 & 11.6 & 8.8 & 12.0 \\
\hline Private consumption deflator & 3.6 & 3.2 & 2.6 & 3.0 & 2.9 & 2.9 & 2.7 & 2.7 \\
\hline Exchange rate: \$/zl & 1.8 & 20.0 & 0.8 & -2.8 & -0.3 & 1.7 & 0.6 & -1.8 \\
\hline
\end{tabular}

Soyrce: own computations 
Domestic activities are predicted to recover slowly in 2010. Private consumption will show a mild increase exceeding $2.5 \%$ due to a rise in real wages and a low inflation rate, all this despite a negligible further decrease in employment. In the following years, wage pressure and growing employment will make the private consumption rate rise to $3 \%$.

We expect a real recovery in investment starting in 2010 (4.5\%). The recovery is expected to peak in 2011-2012, at 15\%-17\%.

These factors will contribute to an increase in final domestic demand by 4\%-5\% in 2011-2012.

Foreign trade will finally recover in 2011-2012, with high rates of growth for imports (10\%-11\%) exceeding those for exports. Consequently, the foreign trade balance will deteriorate.

The unemployment rate will be high, hovering around 12\%, whereas the inflation rate will be rather stable at under 3\%. The country's budgetary position will improve. However, the rising total debt will remain a key policy problem in the coming years.

\section{References}

Bodkin R.G., Klein L.R., Marwah K., [1991], A History of Macroeconometric Model-Building, E. Elgar, Aldershot.

Clemments M.P., Hendry D.F., [2000], Forecasting Economic Time Series, Cambridge University Press, Cambridge.

Eastern Europe Consensus Forecasts, [2009], A Digest of Economic Forecasts, Consensus Economies, London (monthly surveys).

Klein L., Welfe A., Welfe W., [2004], Principles of Macroeconometric Modeling, North Holland, Amsterdam.

Welfe W., [2008], The Structure of a New Long-Term Macroeconometric Model for Poland, „Przegląd Statystyczny", Vol. 55, pp. 5-23.

Welfe W., [2009a], A Medium-Term Forecast for Poland, Deep Slowdown, paper presented at the Project LINK meeting, St. Petersburg, June 4-6, 2009, Łódź.

Welfe W., [2009b], A Medium-Term Forecast for Poland 2009-2011. Stabilization After Slowdown, paper presented at the Project LINK meeting, Bangkok, Oct. 20-26, 2009, Łódź.

Welfe W., (ed.), [2009], Makroekonometryczny model gospodarki opartej na wiedzy (Macroeconometric Knowledge-Based Model), Acta UŁ, Folia Oeconomica, 229, Wydawnictwo Uniwersytetu Łódzkiego, Łódź.

Welfe W., Florczak W., [2009], Prognozy i scenariusze długookresowego rozwoju gospodarczego Polski (Forecasts and Scenarios of Long-term Economic Development of Poland), Wydawnictwo Uniwerstytetu Łódzkiego, Łódź.

Whitely J., [1994], A Course in Macroeconomic Modelling and Forecasting, Harvester Wheatsheaf, New York. 


\section{SLOWDOWN OF THE POLISH ECONOMY: MODEL-BASED SIMULATIONS}

\section{Sum mary}

The global financial crisis, and especially the recession that spread across Europe in 2009, also affected Poland. While the Polish economy continued to grow throughout 2009 , its growth decelerated considerably in quarterly terms.

The paper examines the determinants of the slowdown, based on a simulation macroeconomic model called W8D-2007. The model's properties are briefly outlined, and then a baseline medium-term forecast is introduced and some simulation exercises are shown, dealing mainly with pessimistic scenarios.

By means of simulations based on the W8D model, the paper tries to show the key factors behind the serious slowdown in the Polish economy in 2009. The model examines the impact of declining exports and FDI, on the one hand, and the growing investment risk and positive changes in household consumption, on the other.

The possible impact of fiscal and monetary policies is also examined. The effects of a reduction of income tax rates and social contribution rates as well as the implications of an increased budget deficit are also shown, and finally the impact of declining interest rates on investment and consumer demand is evaluated. The likely effects of measures aimed at constraining the increase of unemployment rates are also analyzed.

The results are compared with changing forecasts for the Polish economy presented during 2009.

Keywords: econometric models, forecasting, simulations, determinants of growth, economic shocks 